JPL $-5030-267$

NOVEMBER 10, 1978

\title{
UTILITY PLANS \\ FOR UTILIZATION OF GEOTHERMAL ENERGY IN CALIFORNIA
}

Prepared for

U.S. DEPARTMENT OF ENERGY

JETPROPULSION LABORATORY

CALIFORNIA INSTITUTE OF TECHNOLOGY

PASADENA, CALIFORIA 


\section{DISCLAIMER}

This report was prepared as an account of work sponsored by an agency of the United States Government. Neither the United States Government nor any agency Thereof, nor any of their employees, makes any warranty, express or implied, or assumes any legal liability or responsibility for the accuracy, completeness, or usefulness of any information, apparatus, product, or process disclosed, or represents that its use would not infringe privately owned rights. Reference herein to any specific commercial product, process, or service by trade name, trademark, manufacturer, or otherwise does not necessarily constitute or imply its endorsement, recommendation, or favoring by the United States Government or any agency thereof. The views and opinions of authors expressed herein do not necessarily state or reflect those of the United States Government or any agency thereof. 


\section{DISCLAIMER}

Portions of this document may be illegible in electronic image products. Images are produced from the best available original document. 
5030-267

NOVEMBER 10, 1978

\title{
UTILITY PLANS \\ FOR UTILIZATION OF GEOTHERMAL ENERGY IN CALIFORNIA
}

Prepared for

\section{U.S. DEPARTMENT OF ENERGY}

\author{
JET PROPULSION LABORATORY \\ CALIFORNIA INSTITUTE OF TECHNOLOGY
}

PASADENA, CALIFORNIA 
UTILITY PLANS FOR UTILIZATION OF GEOTHERMAL

ENERGY IN CALIFORNIA

November 10, 1978

Daniel J. Kerrisk

Prepared for

U.S. Department of Energy

Division of Geothermal Energy

JET PROPULSION IABORATORY CALIFORNIA INSTITUTE OF TECHNOLOGY PASADENA, CALIFORNIA 


\section{ACKNOWLEDGMENT}

The author would like to express his gratitude to the representatives of the electric utilities contacted, both for the information provided and for the review and critique of the individual sections dealing with their utility. These were:

Mr. H. R. Perry, PG\&E

Mr. Frank McCracken, SCE

Mr. J. M. Matosec, LADWP

Mr. Ron Watkins, SDG\&E

Mr. Lloyd Harvego, CDWR

Mr. John J. Mattimoe, SMUD

Mr. Norman Ingraham, NCPA 
CONTENTS

Page

I. INTRODUCTION - 1-1

II. SUMMARY - 2-1

III. DETAILED FACILITY COMMENTS - 3-1

A. PACIFIC GAS AND ELECTRIC COMPANY (PG\&E) - 3-1

B. SOUTHERN CALIFORNIA EDISON COMPANY (SCE) - 3-3

C. LOS ANGELES DEPARTMENT OF WATER AND

POWER (LADWP) - 3-6

D. SAN DIEGO GAS AND ELECTRIC COIPANY (SDG\&E) ---_- 3-7

E. CALIFORNIA DEPARTMENT OF WATER RESOURCES (CDWR) --_ 3-9

F. SACRAMENTO MUNICIPAL UTILITIES DISTRICT (SMUD) - - 3-10

G. NORTHERN CALIFORNIA POWER AGENCY (NCPA) --_ 3-12

IV. CONCLUSIONS - 4-1

REFERENCES -

Figures

1. Planned Geothermal Generating Capacity in

California--1976 Survey _-__- 1-2

2. Planned Generating Capacity in California--

Present Survey -_-2-3 
Early in 1976, JPL conducted a survey of Caij.fornia utilities to ascertain their views on the probable zate of geothermal development in the State of California in the immediate future (Reference 1). At the time the survey was conducted, the only firm utility plans for geothermal generating capacity were for the Geysers dry steam field in Northern California; experimental work on utilization of the hot water fields of the Imperial Valley was in its early stages. All of the utilities contacted indicated a willingness to consider geothermal energy as an alternative to gas- and oil-fired plants, but most emphasized that their prime reliance would be on nuclear power to meet future demand growth. Over the ten-year period 1976-1986, they foresaw a maximum of 2500 MW of geothermal capacity coming on-line, and, of this, $2150 \mathrm{MW}$ was at The Geysers (see Figure 1).

Since that survey was conducted, a number of new factors have entered the utility planning picture. Most significant has been the hardening of attitudes in the State against the installation of nuclear plants, and the emphasis on seeking alternative energy sources. Two major nuclear projects, Sundesert and San Joaquin, have been abandoned, and the passage of stiff regulatory laws governing nuclear installations has made approval of new nuclear projects in the State highly improbable for the foreseeable future. In addition, the State has moved to simplify and accelerate the approval procedure for geothermal plants in particular, and has published regulations intended to reduce the time required for obtaining approval for Notice of Intent (NOI) (to construct an electric generating plant) and for Application for Certification (AFC) (of the proposed generating plant) from the California Energy Resources Conservation and Development Commission (CERCDC) to one year. Previously, this NOI/AFC approval process had been taking two to four years to complete, and was cited by utilities as a major deterrent to commitment to geothermal plants.

Other factors entering the planning equation include the implementation of the Federal Geothermal Loan Guaranty Program, authorized by the Geothermal Research and Develonment Act of 1974 (PL 93-410), but not. yet implemented when the survey was taken; and the additional experience provided by two-and-one-half years of working with the hot water resources of the Imperial Valley.

In view of the changed environment, JPL was requested by the U.S. Department of Energy to update the earlier survey and ascertain the present utility outlook for geothermal energy utilization. This report presents the results of that update. 


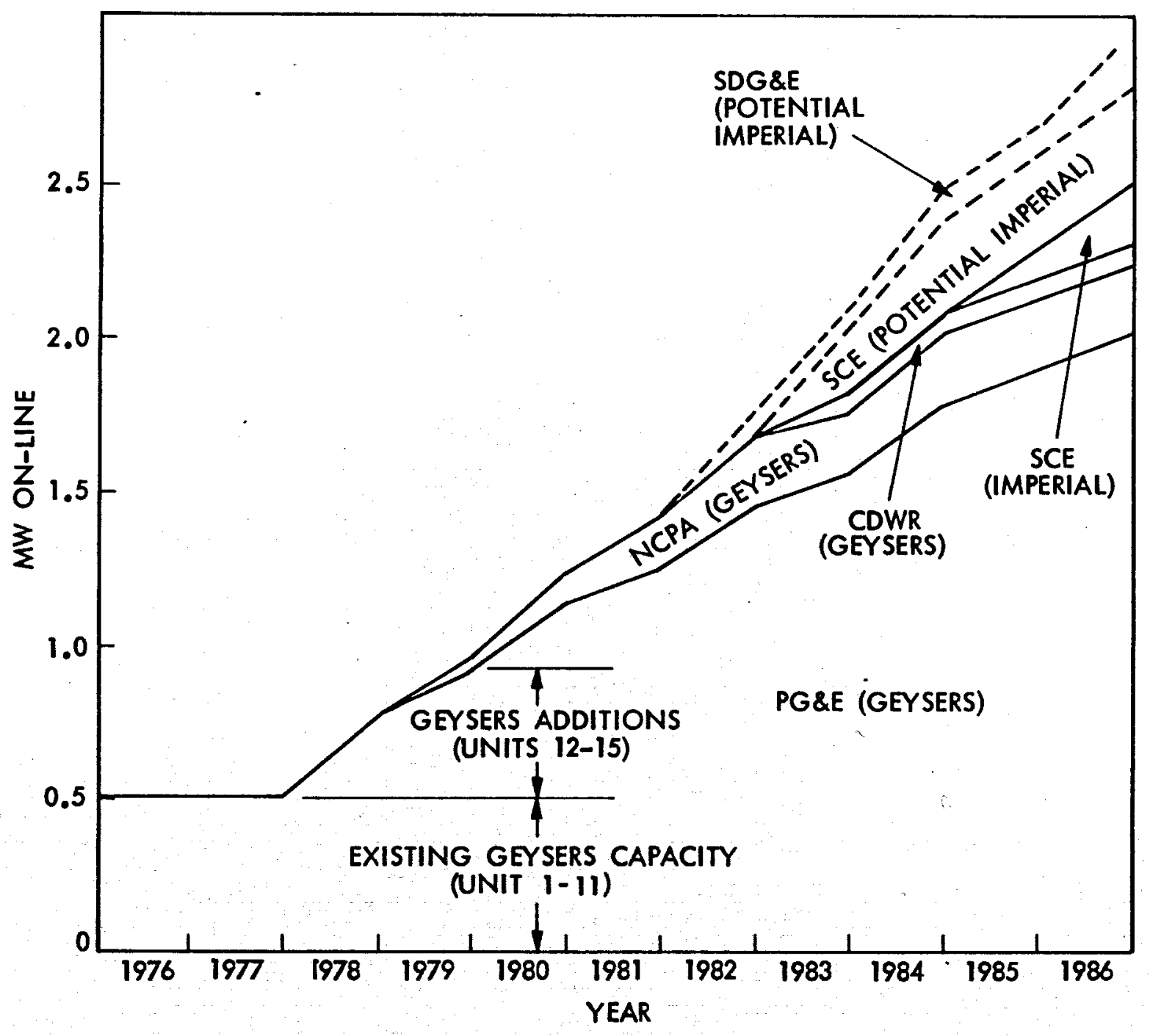

Figure 1. Planned Geothermal Generating Capacity in California--1976 Survey 


\title{
SECTION II
}

\author{
SURTARY
}

In the present survey, seven of the largest utilities in the State, representing over $90 \%$ of the State's electric power generating capacity, were contacted. There were:

Pacific Gas and Electric Company (PG\&E)

Southern Calffornia Edison Company (SCE)

Los Angeles Department of Water and Power (LADWP)

San Diego Gas and Electric Company (SDG\&E)

California Department of Water Resources. (CDWR)

Sacramento Municipal Utilities District (SIIUD)

Northern California Power Agency (NCPA)

(Six of these utilities participated in the earlier survey: the new addition to the list is LADWP.)

The general response to the survey was quite favorable to the development of geothermal energy in concept, but was tempered by many cautions. To start, all of the utilities show some geothermal generating capacity in their long-range capacity addition forecasts submitted to the CERCDC. This is compared to only four with such plans in the earlier survey. In addition, two utilities (SCE and SDG\&E) have announced plans for geothermal plants which do not show in their most recent CERCDC submissions. Still, there has been a retreat, in the rate of geothermal planning from that shown in Figure 1, at least for the early years. There has been no massive shift to geothermal, for example, as an alternative to nuclear planning. The economics of geothermal hot-water plants are foreseen as being too questionable, at least in the immediate future, to compete with other alternatives, and, while there is no hesitation to develop The Geysers as rapidly as possible, that field is generally assumed to be limited to not much more than $2000 \mathrm{lit}$, and it may be limited to less because of air quality considerations.

liost utilities regard coal as the most probable replacement for nuclear energy, and their planning runs in this direction despite the potential environmental problems. They feel current technology coal plants will be cleaner than existing oil-fired plants, and will produce power in the vicinity of $30 \mathrm{mills} / \mathrm{kW}-\mathrm{hr}$ (in 1978 dollars). Geothermal hot-water plants will have to compete with this price before utilities will invest substantially in them, although, at least for first plants, some utilities will accept substantially higher cost-of-power. 
The utflities commitment to development of The Geysers is quite firm, and those most closely involved (PG\&E and NCPA) were quite optimistic that the new State NOI/AFC approval procedures would work as intended, and would help accelerate development of The Geysers. Most other utilities took a more skeptical position, feeling the new procedures, while well-intended, would not significantly reduce the approval cycle, particularly for plants proposed in new areas. These utilities have adopted a wait-and-see attitude while the first NOI/AFC applications to be submitted under the new regulations are processed.

The Geothermal Loan Guaranty Program has not been a factor in utility planning, since no utility feels able to take advantage of it. However, it has had one indirect effect; Republic Geothermal Company has used the loan guaranty to develop its East Mesa field. This field will be used to support the $50 \mathrm{NW}$ power plant Republic itends to build for lease/sale/? to SDG\&E.

Two utilities, SDG\&E and LADWP, cited their current capital position as a major (although not insuperable) deterrent to geothermal investment. Both utilities are counting on purchases of large amounts of power from out of state, rather than installation of their own capacity, to meet load demands of the 1980s. SDG\&E's plans for $100 \mathrm{MW}$ of geothermal power by 1982 are predicated on the required capital investment being made by the field developers, not by SDG\&E.

All utilities indicated their capacity addition forecasts were reasonably firm through 1988 , but beyond that were quite speculative and subject to major change as new information becomes available. Because most geothermal planning, except for The Geysers, falls in the post-1988 period, this uncertainty factor must be considered in evaluating the reliability of all geothermal projections. Thus, for example, a change in the State's attitude toward nuclear projects could halt all hot-water geothermal developments. On the other hand, should presently-planned coal-fired projects not win State approval, or should a shortage of gas and oil cause a major shift of energy demand from these sources to electricity, there could develop an immediate demand for geothermal power at almost any price. In that case, geothermal utilization could grow at a rate impossible to visualize today.

However, leaving aside these possibilities, and recognizing the inherent uncertainties in predicting developments 10 to 20 years in the future, the utilities have provided a reasonably detailed insight into their view of geothermal energy's potential contribution to the State's future electric generation capacity.

Figure 2 shows the composite planning picture of the seven utilities. It was constructed in the following manner:

(1) If The Geysers is limited to $2008 \mathrm{MW}$, which is PG\&E's present planning base, then the sum of developments by PG\&E, NCPA, CDWR, and SMUD in The Geysers cannot exceed this amount. This represents a relatively firm planned development. To 


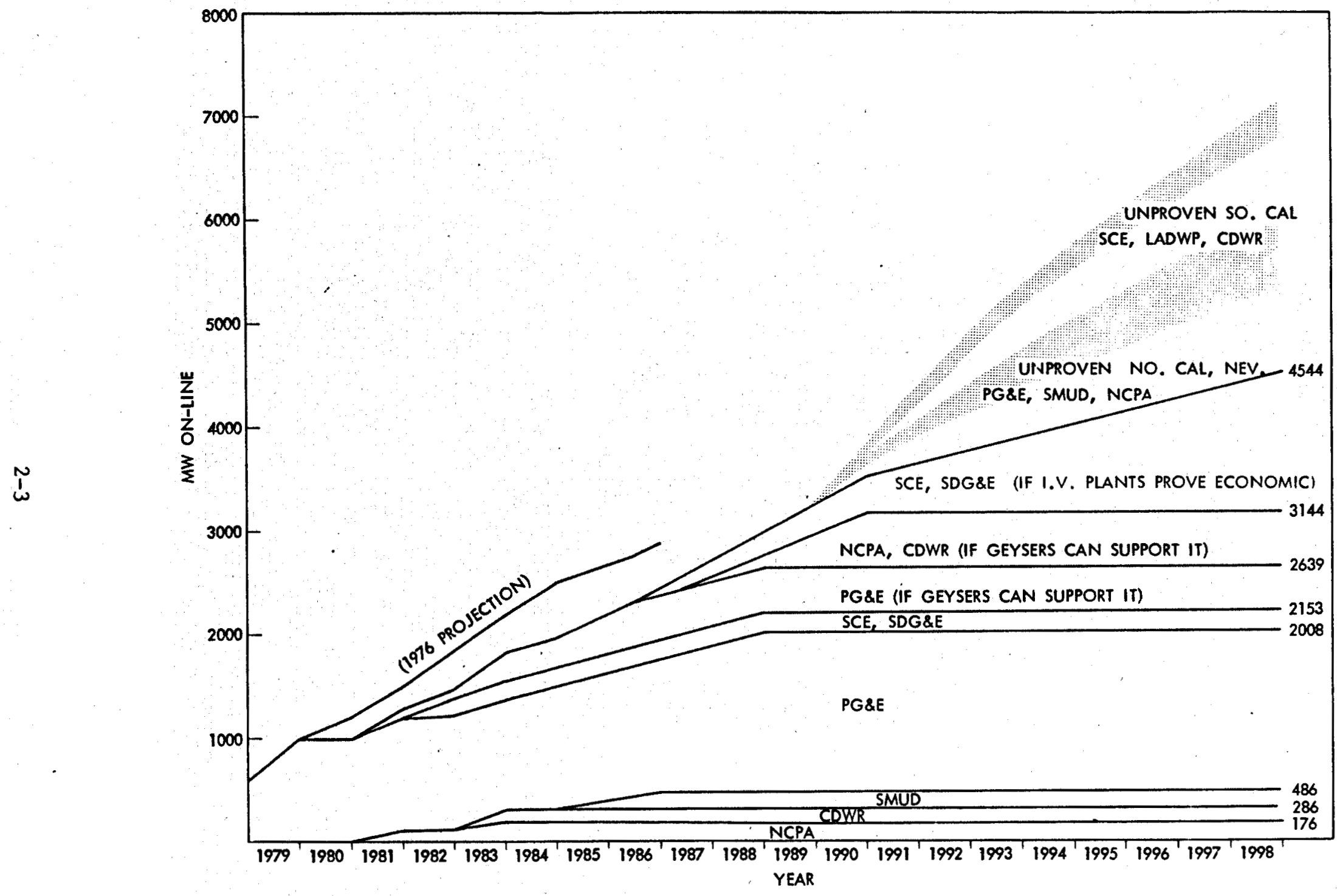

Figure 2. Planned Generating Capacity in California--Present Survey 
this is added the 145 IW announced by SCE and SDG\&E in the Impertal Valley, to give $2153 \mathrm{MW}$ as the minimum anticipated on-1ine geothermal capacity in 1988.

(2) Recent assessments by the USGS (Reference 2) have indicated the probable extent of The Geysers field is much larger than previously supposed. Should steam supplies be available, PG\&E would plan to instal1 2008 MW itself by 1988 . The next increment of the curve reflects this by shifting the $486 \mathrm{MW}$ announced by NCPA, CDWR, and SMUD to add to, rather than be part of, the PG\&E total. This brings the total planned to $2639 \mathrm{MW}$ in 1988.

(3) CDWR has option for an additional $55 \mathrm{MW}$ in The Geysers, and NCPA would like to add another $450 \mathrm{MW}$ there, if the steam supply could support it. While this is speculative at the moment, it is not improbable if the most recent USGS assessment of the steam field's boundaries proves accurate. Adding this in as the next increment brings the total to $3144 \mathrm{MW}$.

(4) Should the economics of the early plants in the Imperial Valley prove favorable, SCE and SDG\&E have planned developments of $1400 \mathrm{MW}$ to be installed in the period 1986-1998, providing the next increment of the curve, and bringing the reasonably anticipatable total to $4544 \mathrm{MW}$ in 1998.

(5) Beyond these developments, we enter the realm of pure speculation, because the resources are not proven. PG\&E has indicated they would plan to continue expansion of their geothermal operations at a rate of about $100 \mathrm{MW}$ per year if a suitable resource were available. SIUD, in consortium with other utilities, is evaluating Northern Nevada resources, and if those resources prove viable could foresee developing as much as $500 \mathrm{MW}$ in the late' 80 s and ' 90 s. NCPA would also be interested in development of hot-water resources if they prove economically viable. If resources suitable for economic power generation are discovered in Northern California or Northern Nevada, then anywhere from 1000 to $2000 \mathrm{MW}$ could be installed by the northern utilities through the end of the century.

(6) SCE, CDWR, and LADWP have a11 expressed interest in deve1op.ing additional geothermal power if suitable resources are proven in Long Valley, Coso, the Imperial Valley, or elsewhere in the southern part of the State. All felt that such developments could not realistically come on-line before the late $80 \mathrm{~s}$; for conservatism, they are shown starting in 1990. Again, there is no way to tell how rapidly such resources might be developed; the curve is based on an arbitrary assumption of 100 to $150 \mathrm{MW}$ per year. 
In summary then, by the late 1980 s it is highly probable there will be at least $2150 \mathrm{MW}$ of installed geothermal capacity in the State, and there is a reasonable probability that his number could be doubled by the mid-1990s. Beyond that, the State's utilities are willing to. speculate that they could accept as much as 2000 to $3000 \mathrm{MW}$ additional geothermal capacity through the 190 s if suitable resources are proven out. This would mean over $7000 \mathrm{MW}$ are possible by 1998 . However, there are many "if's" in such speculation, not the least of which is the emerging attitudes in California and its neighboring States toward nuclear and coal-fired installations.

The detailed comments from each utility follow in Section III. 
SECTION III

DETAILED FACILITY COMMENTS

A. PACIFIC GAS AND ELECTRIC COMPANY (PG\&E)

1. Present Plan for Additional Generating Capacity

The March 1978 PG\&E submission to the Energy Commission of planned capacity additions is shown below (in MW):

\begin{tabular}{|c|c|c|c|c|c|c|c|c|c|c|c|}
\hline Type & $' 78$ & 179 & $' 80$ & $' 81$ & $' 82$ & $\cdot 83$ & $' 84$ & $' 85$ & 86 & $' 87$ & $' 88 * *$ \\
\hline Coal & & & & & & & & 800 & 800 & & \\
\hline Nuclear & 1060 & 1100 & 40 & & 70 & & & & & & \\
\hline $0 i l / G a s$ & 171 & & 184 & 100 & 600 & 200 & 600 & 200 & & & \\
\hline $\begin{array}{l}\text { Hydro- } \\
\text { electric }\end{array}$ & & -4 & 9 & 15 & 102 & & & & & & \\
\hline $\begin{array}{l}\text { Pump } \\
\text { Storage }\end{array}$ & & & & 1125 & & & & & & & \\
\hline Geothermal & 161 & 245 & & 220 & & 220 & 220 & 110 & 110 & 110 & \\
\hline Other* & & & 11 & & 350 & 200 & 50 & 50 & 137 & 98 & \\
\hline \multicolumn{12}{|c|}{$\begin{array}{l}\text { *Includes plants of other types such as } \\
\text { capacity additions of other entities with } \\
\text { which PG\&E is not project manager. } \\
\text { **Type of plant not identifed after } 1987 \text {. }\end{array}$} \\
\hline
\end{tabular}

This plan differs from the one reported in the earlier survey, most notably by the dropping of plans for additional nuclear capacity in the pre-1987 period, and the substitution of $1600 \mathrm{lW}$ of coal-fired capacity. In the earlier survey they had indicated their primary reliance post -1985 would be on nuclear plants; they now feel regulatory approvals in the political environment in the state makes this impractical for the pre-1985 timeframe. Consequently, the shift to coal is required to meet projected load demands.

\footnotetext{
2. Geotherma1 Planning

PG\&E is firmly committed to expansion at The Geysers to its full capacity. The scheduled expansion shown is somewhat out-of-date; PG\&E is now scheduling the completion of installation of $2000 \mathrm{MW}$ in 1988 rather than 1987 as shown.
} 
An important aspect of PG\&E's planning, perhaps not generally recognized, is that PG\&E's projection for Geysers development in their mind includes all Geysers development, including that planned by NCPA, CDWR, SMUD, and any other future potential user, up to what they presently consider to be the total field capability of about $2000 \mathrm{MW}$. Thus if the planned installed capacity of NCPA, CDWR, and SMUD of almost 500 IW goes forward, PG\&E's projected installed capacity for PG\&E would be reduced.

Despite this, PG\&E will continue to install capacity at the Geysers as long as steam supplies are made available, and as rapidly as field development and the regulatory process permit. The recent USGS extension of the probable limits of the steam field gives more hope that PG\&E's present projection of the field's ultimate capability may be conservative, and, while their present planning is based upon a $2000 \mathrm{MW}$ total field capacity, this will not inhibit their pursuit of new steam supplies if they become available. PG\&E could foresee their installing a steady $110 \mathrm{lW}$ a year at the Geysers until the field's ultimate capacity, whatever it may be, is reached; or until other considerations, such as environmental concerns, halt further development.

Along this line, PG\&E points out that the NOI filed for Unit \#16 includes installation of additional transmission lines to bring total transmission capacity up to $2100 \mathrm{MW}$, which they presently foresee as meeting all needs through 1988.

\section{Outlook for Geothermal Energy}

As indicated, PG\&E will install as much geothermal capacity at the Geysers as the field and/or the environment permits. Beyond the Geysers, PG\&E is more tentative. They consider additional nuclear power to be non-viable for future capacity needs at least until the early '90s, and their major alternative is coal. The viability of coal-fired plants in California will soon be tested in the NOI filed by PG\&E with the Energy Commission for Fossil $\# 1$ and \#2, in which four alternative sites are proposed. Commission approval of one of these sites would establish coal-fired plants as viable, and the cost of power from such plants would become the benchmark in determining the viability of other types of capability. P.G\&E indicated that they would be interested in developing hot water resources found in their service area if the cost of power from the plants were competitive with coal, and provided they considered the technology sufficiently well-demonstrated. A projected competitive price would be in the $25-30 \mathrm{mill} / \mathrm{kW}-\mathrm{hr}$ range (1978 dollars). They will be watching with great interest the developments in the Imperial Valley, to demonstrate both the reliability and economic performance of hot-water plants in the United States. If these plants are successful, and a suitable hot water resource were found in their service area (e.g. Clear Lake), PG\&E could foresee hot-water plants on-line in their system, but did not wish to speculate by what date. 


\section{B. SOUTHERN CALIFORNIA EDISON COMPANY (SCE)}

1. Present Plan for Additional Generating Capacity

The most recent plan of SCE for additional generating capacity is shown below (in IW) :

\begin{tabular}{lllllllllllll}
\hline Type & 179 & 180 & 181 & 182 & 183 & 134 & 85 & 186 & 187 & 188 & 189 & 90 \\
\hline Coal & & & & -14 & & & & & & & \\
Oil/Gas & 78 & & & & & 540 & 310 & 825 & 275 & & & \\
Nuclear & 176 & 704 & 363 & 704 & 187 & & 188 & & 750 & & 751 \\
$\begin{array}{l}\text { Geo- } \\
\text { thermal }\end{array}$ & & & & & & & & & & & & \\
Other & 31 & & & 26 & & 140 & 56 & 58 & 114 & 176 & 30 \\
\hline
\end{tabular}

This plan represents a substantial modification downward from the plan reported in JPL Report 5040-25 (Reference 1) in 1976; at that time their forecast showed some 10,000 MW of additional capacity on line by 1990. The present plan reflects the impacts of energy conservation measures and changed public attitudes toward new generating capacity, as we11 as revised projections in the growth of energy demand from population and industrial expansion. SCE emphasized that the present plan specifically does not include provision for a major shift of industrial and commercial energy consumption from fossil fuels to electricity, a shift they feel is highly possible due to future shortages projected for fossil fuels. Further, it still includes $676 \mathrm{MW}$ from the San Joaquin Nuclear Project, which SCE feels is now dead.

\section{Geothermal Planning}

The present plan shows $100 \mathrm{MW}$ of geothermal capacity on line in 1986, with an additional $100 \mathrm{MW}$ on line by 1990 and building to a total of $600 \mathrm{MW}$ by, 1998. This is only slightly different from their earlier projection, which showed $650 \mathrm{MW}$ on line by 1995. However, there have been some significant shifts in the projected locations of this capacity, and activities that do not show in the plan.

SCE's geothermal activities fall into four major areas: Heber, Brawley, Niland, and lono-Iong Valley, and are advanced considerably from the earlier survey; these are summarized below.

a. Heber. SCE is in the process of negotiating with Chevron 0i1 Company for the steam supply for a $50 \mathrm{MW}$ (45 MW net) double-f1ash geothermal power plant at Heber, to be on-line in 1932. This will be 
the first double-flash system built in the U.S., and will be built and funded by SCE. Projected cost of delivered power from the plant is in the range of 50-70 mills/kWh, considerably higher than present generating costs, and does not include transmission costs. SCE feels, however, that this is not out-of-line with future generating costs, and the only way to get geothermal started is to build the plant. Because of the plant size, SCE is not required to obtain from the PUC a certificate of Public Convenience and Consent authorizing the electric power costs; however, SCE will file an information brief with the PUC indicating the probable cost and its intention to include these costs in future rate negotiations. A negative PUC response, indicating they would not allow the inclusion of power generated at this cost in determination of the rate structure would probably kill this project. However, SCE does not expect such PUC action.

b. Brawley. SCE has negotiated contracts with Union Oil Company providing for the purchase by Edison of a $10 \mathrm{MW}$ plant to be built by Rogers Engineering Co. for Union at their Brawley field. This will be presumably a single-flash system, with Union maintaining responsibility for production and well-maintenance, steam separation, and injection. A $10 \mathrm{MW}$ plant size was selected instead of a $50 \mathrm{MW}$ size because of the much higher salinity of the Brawley brine and the associated higher risk. This plant is scheduled to be on-line in late 1980.

c. Niland. In the earlier survey it was reported that SCE's geothermal plans were contingent on a successful development of directflash technology for the hypersaline brines of the Salton Sea area. This effort has been delayed, and SCE's forecasts of power-on-1ine in the late $1980^{\prime} s$ and $1990^{\prime}$ 's are now more predicated on expansion at Heber and Brawley. However, SCE maintains a very active interest in Niland, and plans to go forward with the technology program previously mentioned. SCE has formed a joint venture with Southern Pacific Land Company and Union 0il. Contracts have been executed calling for performance of a \$10-million, 2-year field development program to optimize the techniques for handling the hypersaline Niland brine followed by construction of a $10 \mathrm{MW}$ single flash plant to be operational by mid-1982.

d. Mono-Long Valley. SCE continues to maintain an active interest in the possibility of providing a district hot-water heating system for Mammoth Village. A significant negative factor in the feasibility of the project is its low use factor because of the seasonal nature of the demand, and the 1 imfted amount of resource available due to lack of federal geothermal leases. SCE has been working with the Ben Holt Company under a California Energy Commission grant on a nonelectric heating demonstration system at a lumber yard using the Casa Diablo resource. After some initial difficulties with the well and pump equipment, this project is now proceeding. 


\section{Outlook for Geotherma1 Energy}

SCE is pursuing a wide variety of alternative energy sources, including geothermal energy. They foresee an important role for geothermal in their future plans, but also feel that some of the past projections for growth in geothermal utilization are much too high. They cite in particular the regulatory environment and the problems associated with obtaining popular acceptance of geothermal (or any other kind of) power plants. They note that the Energy Commission has yet to approve a single new power plant site in the State, and while recognizing the improvements in the new NOI/AFC procedures, expressed some doubts as to their efficacy. The sizing of the Heber plant was specifically selected to avoid the need for obtaining CEDCDC site approval.

SCE also foresees that geothermal energy may have difficulty in competing economically with other base load energy technologies; in particular, nuclear and coal. They feel they have the technology now to build coal-fired plants that would be cleaner than their present oilfired capacities, at a cost of power less than that projected for the proposed Heber plant, and cite this technology is perhaps a more probable substitute for the large amount of new oil-fired capacity in the late 80 s shown in the plan than would be geothermal. They do, however, see a continuing role for geothermal energy in their plans, but emphasize the importance of public attitudes toward any type of power plant in determining the role that type of power plant will play in their future plans.

In summary, the SCE picture is as follows:

(1) SCE is pursuing a vigorous geothermal program, with three power plants firmly planned at Heber, Brawley, and Niland.

(2) SCE feels that the present pace it plans for geothermal development is about right, considering the present regulatory environment, the public attitudes toward geothermal development, and the probable emergence of other alternative energy technologies.

(3) SCE does not agree with the more optimistic projections of growth in geothermal utilization in the state, and feels they have been in some measure counter-productive in meeting the state's future energy needs. They have also a skeptical attitude toward the efficacy of the proposed new NOI/AFC procedures in accelerating geothermal development. 
C. LOS ANGELES DEPARTMENT OF WATER AND POWER (LADWP)

1. Present Plan for Additional Generating Capacity

The October 1978 approved LADWP supply plan for added generating capacity is shown below (in MW).

\begin{tabular}{|c|c|c|c|c|c|c|c|c|c|c|c|c|}
\hline Type & 179 & $' 80$ & $' 81$ & $' 82$ & 183 & 184 & $' 85$ & $' 86$ & $' 87$ & $' 88$ & $' 89$ & 190 \\
\hline Coal & 205 & 5 & & -70 & & -70 & -73 & -70 & 256 & 256 & 256 & 256 \\
\hline 0i1/Gas & & & & 460 & & & & & & & & \\
\hline Nuclear & & & & 70 & & 70 & & 70 & & & 148 & 148 \\
\hline Geothermal & & & & & & & & & & & & \\
\hline Solar & & & 2 & & & & & & & & & \\
\hline
\end{tabular}

This plan reflects a considerable amount of modification from previously submitted LADWP plans. The modifications were necessitated by the removal of the Sundesert and San Joaquin nuclear projects, which account for $1110 \mathrm{MW}$ of the previously planned nuclear capacity additions. LADWP is currently investigating the feasibility of a coal plant in Nevada to make up this deficit.

\section{Geothermal Planning}

Geothermal capacity of 5 MW was previously planned on-1ine in 1981; this was to have been LADWP's share of the proposed Heber demonstration plant. This plant will not be built, and LADWP has no firm plans for other geothermal plants at this time.

\section{Outlook for Geothermal Energy}

While LADWP has no geothermal generating capacity in its supply plan, it maintains an active interest in the possibility. The Department has conducted exploratory talks with Union 0il Co. on possible participation in the development of the North Brawley field and with McCulloch 0i1 Co. for development of their holdings. LADWP has extensive land holdings in the Long Valley area, and are considering the advisability of participating in the upcoming bidding on the Forest Service lands. They are also following the efforts on the Navy lands at Coso Hot Springs, and may respond to the anticipated Request for Proposals which the Navy is expected to issue for development of the Coso field.

LADWP indicated two points which loom very large in their thinking. The first is that geothermal, to be of interest to them, must be competitive in cost with coal and nuclear power imported from other states. This implies power production costs of less than $30 \mathrm{mills} / \mathrm{kw}-\mathrm{hr}$. 
The Department did not see how at this time it could plan to incorporate power costs of $50 \mathrm{mills} / \mathrm{kw}-\mathrm{hr}$ (or higher) in its generating capacity mix. However, they will watch with great interest the activities of SCE and SDG\&E in the Imperial Valley.

The second point, stressed by LADWP, was the inability of their present capital position to finance major projects, and its effect on their decision process. The Department indicated that its interest in the Intermountain Power Project, and in the potential Nevada coal plant, was predicated on others providing the up-front capital for plant development. LADWP would be willing to sign firm long-term contracts to buy energy, as long as they were not required to make a large initial investment. Arrangements similar to SDG\&E's arrangements with Magma and Republic, in which the energy company finances the plant construction, would be very appealing to LADWP. However, they have not ruled out investment in geothermal plant construction, or even in exploration for new resources.

The Department has no doubts as to the availability of a reliable technology for geothermal energy conversion, only to the competitiveness of its economics within environmental constraints. Once convinced that the economics of geothermal power were competitive with coal and nuclear power, LADWP would probably commit to available geothermal facilities. However, they do not foresee this as likely in the near future.

Another area which LADWP is following with interest is the hybrid concept (geothermal-assisted coal fired plant) being pursued by the city of Burbank. Roosevelt, Utah, and Beowawe, Nevada, were cited as potential sites for such plants, and the Department might be interested in participating in a project at either site. However, the Department regarded as unrealistic the possibility of such a plant being approved in California.

In summary, LADWP has adopted a wait-and-see attitude toward geothermal energy. The Department is receptive to potential joint ventures in geothermal development, if they can be convinced the economics makes them competitive with out-of-state nuclear and coalfired plants. They would be particularly receptive to ventures which minimize their own front-end capital investment. However, they have no firm plans at this time, and foresee meeting the need for all their added generation through the 1980 s primarily by participation in the joint ownership of out-of-state nuclear and coal-fired generation. Unless there is a major change in the present situation, the earliest that they could foresee any significant geothermal component in their planned generation additions would be in the latter part of the 1980s.

\section{SAN DIEGO GAS AND ELECTRIC COMPANY (SDG\&E)}

1. Present Plan for Additional Generating Capacity

SDG\&E's most recent plan for adding capacity to their system is divided into three parts: those plants to which they are firmly committed, near term potential capacity, and long-term potential capacity. 
Their firm commitments past 1979 include only their $20 \%$ interest in San Onofre, which will add 240 MW to their system over the period of 1980-1983.

Near-term plans include. the purchase of up to $300 \mathrm{MW}$ of power from Eastern resources over the period 1981-1990, and purchase of up to 300 MW of power from Mexico over the period 1982-1986.

Their long range plans have four elements: (1) ownership of up to $300 \mathrm{MW}$ of Eastern resources, in the period 1988-1992; (2) installation of up to $800 \mathrm{MW}$ of geothermal generation capacity, over the period 19821990; (3) addition of up to $600 \mathrm{MW}$ of capacity by re-powering existing plants; and (4) eventual development of the Blythe site (Sundesert), with up to $1000 \mathrm{MW}$ added over the period 1988-1992.

While SDG\&E expects that each of these types of elements will figure in their future capacity additions, they feel that this method of reporting more realistically reflects the uncertainties involved in reporting planned additions which are as yet uncommitted.

\section{Geothermal Planning}

SDG\&E has recently announced the signing of letters of interest with both Repub1ic Geothermal and Magma Power Company for the operation of geothermal plants at East Mesa and Niland, respectively, in the Imperial Valley. Both plants are $50 \mathrm{MW}$, and will be built and financed by the development companies. Both should be on-line in the early 1980s. The terms under which SDG\&E will operate the plants are yet to be worked out, and SDG\&E emphasized that many matters, including the obtaining by the developers of financing for the plants, are still uncertain. However, the present SDG\&E plan for installation of $800 \mathrm{MW}$ of geothermal capacity in the Imperial Valley is predicated on successful operation of these plants.

In the earlier survey, it was indicated that much of SDG\&E's geothermal planning was predicated on the planned transmission line across the Imperial Valley, to be installed as part of the Sundesert Project. Even without Sundesert, however, SDG\&E does not now foresee transmission as a limiting factor on geothermal growth. Their need to purchase power from the East and Mexico will still require the installation of new transmission capability.

\section{Outlook for Geothermal Energy}

SDG\&E anticipates the cost of power from the first plants in the Imperial Valley will be in the range of 60 to $100 \mathrm{mills} / \mathrm{kW}-\mathrm{hr}$, depending on the capacity factor achieved. At the lower end, at least, they feel this will be competitive with oil fired capacity. It will not be competitive with coal-fired or nuclear power generation, but SDG\&E feels on the basis of past experience that neither of those types of generating capacity will be allowed in California in the foreseeable future. 
Consequently, they are emphasizing geothermal. They anticipate no difficulty with the PUC in obtaining approval of these magnitudes of power costs for these two plants in future rate negotiations.

SDG\&E foresaw little impact on the cost of power from the early plants due to the fact they would be built by unregulated companies, who would presumably require a higher rate of return on invested capital than would a utility. They cited compensating factors, and in particular the availability of investment tax credits to the developers, which would offset the higher capital cost. They noted their own capital position would not allow SDG\&E to take advantage of such credits.

SDG\&E did not feel that any acceleration in their present schedule for adding geothermal capacity was possible. They cited the need for obtaining operating experience with the plants coming on-line in 1982 before committing to further plants, and then the normal approval and development/construction cycle, as making 1986 about the earliest that new plants could be expected. The rate of growth beyond 1986 was set by normal prudent practice in field expansion and development, and is if anything optimistic.

SDG\&E does not find realistic the projections showing as much as $20,000 \mathrm{MW}$ of geothermal power on-line in California by the year 2000 . They cite the unknown character of the resource, and the questionable economics. They noted their own plans were highly tentative, and would change drastically if the outlook for installation of nuclear or coa1fired capacity in California improved.

\section{E. CALIFORNIA DEPARTMENT OF WATER RESOURCES (CDWR)}

1. Present Plan for Additional Generating Capacity

The proposed generating capacity additions of the CDWR, according to their most recent forecast to the Energy Commission, are shown below (in MW):

\begin{tabular}{lllllllllllllllll}
\hline Type & 179 & 180 & 181 & 182 & 183 & 184 & 185 & 186 & 87 & 88 & 89 & 90 \\
\hline
\end{tabular}

Hydro

90 5

Geothermal

Other

141

These capacity additions represent only a small portion of CDWR's projected future energy needs. In the earlier survey, the Department had indicated it was also considering participation in the San Joaquin and Sundesert nuclear projects. The Department is now considering geothermal, coal, and purchases of capacity and energy to provide for its future energy needs. One of the alternatives high on the Department's interest list is geothermal energy. 


\section{Geothermal Planning}

The Department is now firmly committed to the installation of 110 MW of generating capacity at The Geysers, to go on-1ine in 1983. The NOI for the first of these plants has been filed with the Energy Commission, and the NOI for the second plant is scheduled for filing in March of 1979. The Department also has options on a third 55 MW plant in The Geysers region, provided the steam supply is proven out. This represents a substantial acceleration in commitment to geothermal energy over that shown in the earlier survey, which showed a single 50 MW plant on-line by 1983, and no further plants firmly planned.

\section{Outlook for Geothermal Energy}

CDWR is also interested in the hot water resources of the Imperial Valley, and are following developments there closely, although they have no firm plans or commitments at this time. Realistically, however, the Department foresees no generating capacity in the Imperial Valley before the late 1980 s at the earliest.

\section{F. SACRAMENTO MUNICIPAL UTILITIES DISTRICT (SMUD)}

1. Present Plan for Additional Generating Capacity

SMUD's submission of September 1977 to the Energy Commission for planned capacity additions is shown below (in MW):

\begin{tabular}{|c|c|c|c|c|c|c|c|c|c|c|c|c|c|}
\hline Type & 179 & $' 80$ & 81 & $' 82$ & $' 83$ & $\cdot 84$ & $' 85$ & ' 86 & $' 87$ & $' 88$ & $: 89$ & 90 & ' 91 \\
\hline $0 i 1 / \mathrm{Gas}$ & & & & & 150 & & & & & & & & \\
\hline Nuclear & & & & & & & & & & & & & 1100 \\
\hline $\begin{array}{l}\text { Geo- } \\
\text { therma1 }\end{array}$ & & & & & & & 100 & 100 & & & & & \\
\hline
\end{tabular}

In the earlier survey, SMUD had indicated their primary planning for meeting future load needs centered on nuclear capacity, specifically on expanding its Rancho Seco plant. The 1100 . WW shown in 1991 is for. Rancho Seco \#2. However, SMUD now believes in the present Californian environment that it is not realistic to plan on a firm operational date for any additional nuclear capability and has therefore shifted its planning emphasis to coal. SMUD is using the NOI process for PG\&E's Fossil $\# 1$ and $\# 2$ plants as a bellwether for the viability of additional coal-fired generating plants in California. If the Energy Commission finds more than one of the four sites proposed by PG\&E for Fossil $\# 1$ and \#2 to be environmentally acceptable for the construction of coal-fired capacity, SMUD would be encouraged to firm up its own plans around coal. 
Should PG\&E encounter great difficulty in obtaining siting approval for Fossil $\#_{1}$ and $\# 2$, however, SMUD recognizes it may have a large hole in its future capacity planning.

\section{Geothermal Planning}

SMUD is currently planning on the installation of $200 \mathrm{MW}$ of geothermal capacity, and is currently negotiating with energy companies in The Geysers area for the necessary steam supplies. The utility district thus becomes the fourth utility actively competing for The Geysers steam.

In the earlier survey it was reported that SMUD also was conducting preliminary negotiations for a potential hot water plant in the northeast region of the State. SMUD now indicates they have abandoned this interest, in the vicinity of Honey Lake, because the temperature of the resource was too low for economic development.

\section{Outlook for Geothermal Energy}

Because of the general uncertainty in obtaining environmental approval of any new generating capacity, SMUD is very interested in potential additional geothermal plants. While they would be interested in more capacity at The Geysers, they do not feel it can be realistically planned at this time, considering the total capacity now scheduled for installation at The Geysers, and the probable extent of the field. Therefore, their attention for potential future plants has shifted to hot water resources.

SMUD has joined a consortium of six utilities, including Sierra Pacific Power and PG\&E, to evaluate potential geothermal sites in northern Nevada. They are hoping to find resources capable of producing power at costs in the range of $30-35 \mathrm{mills} / \mathrm{kW}-\mathrm{hr}$, which they feel would be competitive with their tentatively planned coal-fired capacity. They are principally interested in resources that could support flash-steam plants, because they feel this technology is well proven. They expressed less interest in binary-cycle technology such as is planned for at least two of the Imperial Valley plants.

Given a resource which satisfies their requirements, SMUD and the consortium would anticipate building a pilot plant in the 10-20 MW range. While they gave no date for such a plant to be on-line, the mid-1980s would seem a reasonable expectation. If the pilot plant proves successful, SMUD anticipates the consortium would develop the field to its full potential. SMUD would hope this would be at least 400 to 500 MW. However, this power could not reasonably be expected to come on-1ine before the early 1990s. 
G. NORTHERN CALIFORNIA POWER AGENCY (NCPA)

1. Present Plan for Additional Generating Capacity

\begin{tabular}{|c|c|c|c|c|c|c|c|c|c|c|c|c|}
\hline Type & 179 & 80 & $' 81$ & $' 82$ & 183 & $' 84$ & 85 & 86 & 187 & $' 88$ & 189 & $' 90$ \\
\hline Hydro & & & 206 & & & & & & & & & \\
\hline Nuclear & & & & & & $26 *$ & & & & & & \\
\hline Geothermal & & & 110 & & & 66 & & & & & & \\
\hline
\end{tabular}

NCPA is comprised of the power agencies of the cities of Redding, Roseville, Biggs, Gridley, Ukiah, Healdsburg, Alameda, Lodi, Santa Clara, Lompoc, and Palo Alto, and the Plumas-Sierra Rural Electric Cooperative. Up to the present they have been distributors of power only, with no generating capacity of their own. As shown, this will change in the near future.

\section{2: Geothermal Planning}

NCPA is planning to install $176 \mathrm{MW}$ at The Geysers, with the first $110 \mathrm{MW}$ installed by 1981. The NOI for these units has been filed, and will be the first to test the new CERCDC NOI/AFC approval procedures. NCPA expressed great confidence in the Commission's ability to meet the twelve-month approval cycle goal, and expects to be able to start construction in 1979. The second installation is planned to be on-1ine in 1983.

Beyond these two installation, NCPA had been planning a $2 \%$ participation in the San Joaquin nuclear plant. This project is now effectively dead, and NCPA will look to geothermal to replace its interest.

\section{Outlook for Geothermal Energy}

NCPA foresees the installation of as much as $450 \mathrm{MW}$ of additional geothermal capacity through the 1980 s, if adequate geothermal resources are proffered. The Agency is encouraged by the recent USGS assessment extending the probable boundaries of The Geysers steam field, but emphasized its interest was not restricted to The Geysers. NCPA would also be interested in hot water resources, provided adequate conversion technology had been demonstrated. They are following with interest the developments in the Imperial Valley, where SCE and SDG\&E have announced plans to operate hot water plants in the early 1980s. Although NCPA has no interest in the Imperial Valley per se, they feel the technology 
demonstrated there could lead to their own installation of hot water plants in Northern California by the end of the decade, if such hot water resources become available.

Looking further into the future, NCPA foresees for itself a capacity mix based on nuclear and geothermal resources. The Agency indicated its present load of $642 \mathrm{MW}$ is expected to grow by over $50 \%$ by 1985, and, since it is starting from a capacity base of zero, anticipates the need for additional capacity of both types. Their present nuclear plans center about participation in the presently hypothetical Rancho Seco Unit No. 2, in which they have requested a $10 \%$ share.

In summary, NCPA is enthusiastic about their future in geothermal energy, and foresees an agressive program in development of geothermal capacity. They feel the CERCDC will be successful in its present efforts to ease the regulatory snarl that has been cited as a principal deterrent to geothermal development, and cite their own experience as proof of the sincerity of the Commission's intent. Given this favorable regulatory environment, NCPA could have on-line over $600 \mathrm{MW}$ of geothermal generating capacity by 1990 , if adequate geothermal resources are made available. 
SECTION IV

CONCLUSIONS

From the foregoing, it is evident that California utilities intend to develop The Geysers at the maximum rate and to the maximum extent that regulatory agencies will permit, up to the capacity limit of the field. This should be reached by the end of the 1980 s, if the field capacity is in the range of 2000 to $3000 \mathrm{MW}$.

Beyond The Geysers, the course of further geothermal development hangs on a large number of "ifs":

(1) If the initial plants in the Imperial Valley demonstrate at least the potential of future geothermal plants to produce power at costs near $30 \mathrm{mills} / \mathrm{kW}-\mathrm{hr}$ in 1978 dollars; and

(2) If suitable resources are discovered over the next five years; and

(3) If there is no major shift in State policy toward nuclear power generation;

then it is reasonable from the utilities' comments to conclude that as much as $4000 \mathrm{MW}$ of geothermal energy from hot water plants could come on-line by the end of this century. On the other hand,

(1) If the Imperial Valley plants fail to demonstrate promising economics; or

(2) If suitable resources are not found; or

(3) If there is a major softening of State policy toward nuclear power;

then there could be Iittle significant hot-water generating capacity installed in the State for the remainder of the century. However,

(1) If coal-fired generation capacity is disallowed for environmental reasons, or so burdened with restrictions that its cost escalates substantially beyond present projections; or

(2) If power demand grows more rapidly than presently projected, e.g., due to a major shift of industrial energy loads from ol1 and gas to electricity; or

(3) If large amounts (several thousand megawatts) of power cannot be purchased from out-of-state sources; or

(4) If polictes adopted by the Federal and State governments (such as, for example, provision of a geothermal depletion allowance) significantly reduce the present projected costof-power from hot-water plants; and 


\section{(5) If sufficient suitable resources are found;}

then the rate of development projected here could be too conservative, and could become a function only of the rate of resource discovery.

There is no way at the present time to distinguish the relative probabilities of each of these potential outcomes. From the utility viewpoint, all are acceptable; their sole concern is providing adequate power to customers at the lowest possible cost, whatever this implies in generation type. Faced with this uncertainty, all their plans for capacity mix beyond the mid-'80s are tentative and subject to external influences. These influences are at present leading them to at least consider the geothermal alternative, as reflected in their comments. However, given the volatility of the entire energy picture in the State, there can be no definitive conclusion reached here as to the utilities' view of the probable future of geothermal energy. As much as five more years may be needed before reliable predictions can be made. 


\section{REFERENCES}

1. Report on the Status of Development of Geothermal Energy Resources in California, JPL Report 5040-25 (Rev. A), Jet Propulsion Laboratory, Pasadena, CA 91103, June 1976.

2. Goff, F. E., Donnel1y, J. M., Thompson, J. M., and Hearn, B. C., Jr., "Geothermal Prospecting in The Geysers-Clear Lake Area, Northern California", Geology, V. 5, No. 8, pp. 509-515, Geological Society of America, Boulder, Co 80301, August 1977. 